\title{
Comparison of different biogas use pathways for Latvia: biogas use in CHP vs. biogas upgrading
}

\author{
Ilze Dzene, Francesco Romagnoli, Gundega Seile, Dagnija Blumberga \\ Institute of Energy Systems and Environment, Riga Technical University, Kronvalda boulev. 1, Riga LV1010, Latvia
}

\begin{abstract}
In order to contribute to the European 20-20-20 targets, Latvia has committed to increase the share of renewable energy in the final energy consumption from $34.9 \%$ in 2005 up to $40 \%$ in 2020 . Within these ambitious targets biogas will play important role. Biogas can be used following different pathways: direct combustion with the production of only heat, combined heat and power (CHP) generation, or it can be upgraded to biomethane and later used as vehicle fuel or injected in the natural gas grid. In this light an important question is raising about what is the most feasible pathway of the biogas use. The assessment of the feasibility and performance of a single pathway cannot be based only on economic criteria like costs and related economical benefits. Therefore in this study the assessment is done through a multidisciplinary approach that involves not only economical, but also environmental and social perspectives. The main purpose of this study is devoted to the analysis of different biogas use pathways under a specific set of proper criteria based on a literature review. Scenarios under assessment include direct biogas combustion, use of biogas in a CHP system, and biogas upgrading to biomethane. The identified set of criteria is applied to the Latvian biogas market as a case study in order to provide a consistent and holistic final overview.
\end{abstract}

Keywords: biogas pathways; biomethane; biogas upgrading; CHP; multi-criteria analysis.

\begin{tabular}{|ll|}
\hline \multicolumn{2}{|l|}{ Nomenclature } \\
$\mathrm{CBG}$ & compressed biomethane (biogas) \\
$\mathrm{CH}_{4}$ & methane \\
$\mathrm{CNG}$ & compressed natural gas \\
$\mathrm{CO}_{2}$ & carbon dioxide \\
$\mathrm{CHP}$ & Combined Heat and Power System \\
$\mathrm{DH}$ & District Heating \\
$\mathrm{GHG}$ & greenhouse gas \\
LCA & life cycle assessment \\
MCA & multi-criteria analysis \\
TOPSIS & Technique for Order of Preference by Similarity to Ideal Solution \\
\hline
\end{tabular}

\section{Introduction}

The main European energy and environmental policy driver is the 20-20-20 goal, where each Member State contributes to the goal of $20 \%$ increase in energy efficiency, $20 \%$ reduction of $\mathrm{CO}_{2}$ emissions, and $20 \%$ renewable by 2020 [1]. In January 2014 European Union announced a target for 2030. Europe will cut its greenhouse gas emissions by $40 \%$ and will produce $27 \%$ of its energy from renewable sources by 2030 [2].

Biogas is a valuable source of energy. Compared to other biofuels, biogas is appropriate for various kinds of use and in that sense can compete with natural gas. Biogas can be used not only for heat and electricity production, but also as fuel for vehicles. Thus biogas as renewable energy source is contributing to renewable energy targets in all three energy demand sectors - heating and cooling, electricity and transport. Each country should decide for which sector the biogas will contribute the most. Accordingly appropriate policies to support one or the other way of biogas use should be designed.

Corresponding author: Francesco Romagnoli. E-mail address: francesco.romagnoli@rtu.lv http://dx.doi.org/10.3846/enviro.2014.017

(C) 2014 The Authors. Published by VGTU Press. This is an open-access article distributed under the terms of the Creative Commons Attribution License, which permits unrestricted use, distribution, and reproduction in any medium, provided the original author and source are credited. 
Several studies comparing biogas utilization pathways have been conducted lately. Goulding, D. et al. determined the optimum small to medium scale biogas technology and the impact the introduction of that technology infrastructure will have on renewable energy targets for Ireland [3]. Authors concluded that the most suitable crop for biogas energy production in Ireland is grass silage and biogas upgrading to biomethane as transport fuel has the optimum technology potential. The determination of the optimum technology was based on net profit per hectare of land area (€/ha). In Ireland biomethane can compete in terms of sale price against diesel and petrol while biogas to CHP technology is hindered by unavailability of a market for heat.

Pöschl, M. et al. evaluated various biogas production and utilization pathways from the energy efficiency point of view [4]. Authors have made assessment of existing biogas systems and technologies for biogas system operating conditions in Germany. According to their conclusion the most efficient utilization pathway for small scale biogas plants is CHP generation with heat utilization at relatively short transmission distance (up to $2 \mathrm{~km}$ ), but for a large-scale biogas plants the best way would be upgrading of biogas for gas grid injection, but using small-scale CHP to service biogas production process (heating of digesters) and biogas upgrading energy loads.

Murphy J.D., et al., assessed biogas utilization options from the greenhouse gas (GHG) emissions saving perspective [5]. Authors conclude that in terms of GHG production the only sustainable option is to use most of the biogas for upgrading to transport fuel and use minor part for a small scale CHP generation on site.

In Sweden Börjesson, M. and Ahlgren, E.O. investigated what would be the cost-effective way of biogas utilization in the region of Västra Götaland [6]. The analysis in their study covered two potential sectors for biogas use: as vehicle gas in the transport sector and for heat or CHP generation in the district heating (DH) sector. The conclusion from the study is that from a techno-economic perspective biogas is better used as vehicle gas in the transport sector than as fuel in the DH sector. They also admit that whereas replacement of oil based transport fuels clearly is an effective measure to approach energy security of supply objectives, the question whether use of biogas for CHP generation or as vehicle gas is more effective in terms of $\mathrm{CO}_{2}$ reduction (environmental perspective) is more ambiguous and depends, for instance, on marginal production technology in the electricity system.

From the literature review analysis we can see that several studies trying to determine the best ways of biogas use have been prepared. However, the evaluation is based on different criteria. Some of the studies are taking into account costeffectiveness (economic criteria), some use energy efficiency (technical criteria); some assess GHG emission savings (environmental). In this paper authors are proposing a methodology that can be used for evaluation of biogas use pathways by taking into account not only one type of criteria, but rather to use a set of selected criteria from economic, environmental and technological point of view. The proposed method is based in multi-criteria analysis and can be used by policy makers for designing further support policies for biogas sector on national level.

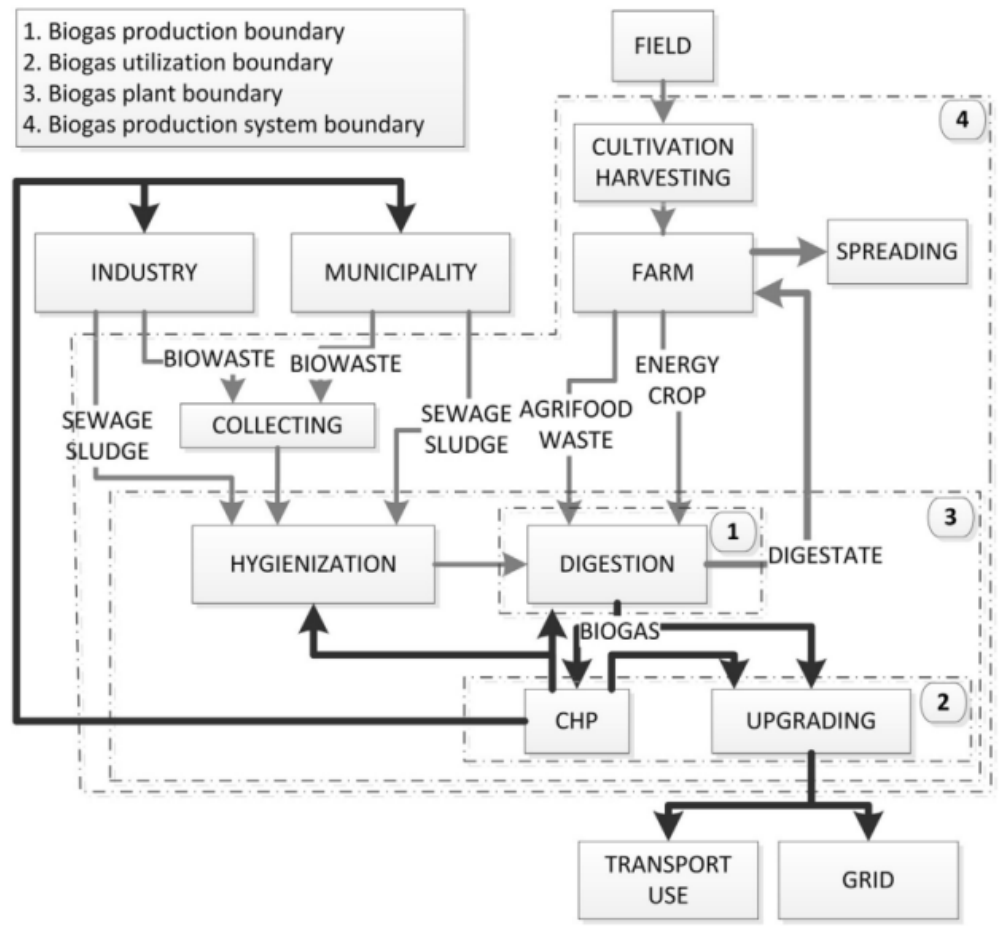

Fig. 1. Biogas production system and its boundaries according to [1] 


\section{Materials and methods}

\subsection{Defining system boundaries}

Biogas systems and biogas in general has undergone extensive research, resulting in a multitude of research papers about biogas production, biogas production improvements, different process configurations, energy performance of biogas production etc. Havukainen J. et al. report [1] that it is essential for comparability of biogas plants that their energy performance would be calculated in a more consistent manner in the future. As a result the authors of the above mentioned study identified various system boundaries and evaluating methods for estimating energy performance of biogas production. They distinguish four system boundaries: (1) biogas production boundary, (2) biogas utilization boundary, (3) biogas plant boundary and (4) biogas production system boundary (see Fig. 1).

In order to analyse all biogas-to-energy conversion pathways in this study the authors decided to extend the biogas utilization boundary (2) as suggested by Havukainen J. et al. [1] to external use that is not necessarily on the same geographical location with the biogas production system (respectively, outside the biogas production system boundary (4)). Figure 2 describes the boundary of this study, including all considered biogas-to-energy conversion pathways.

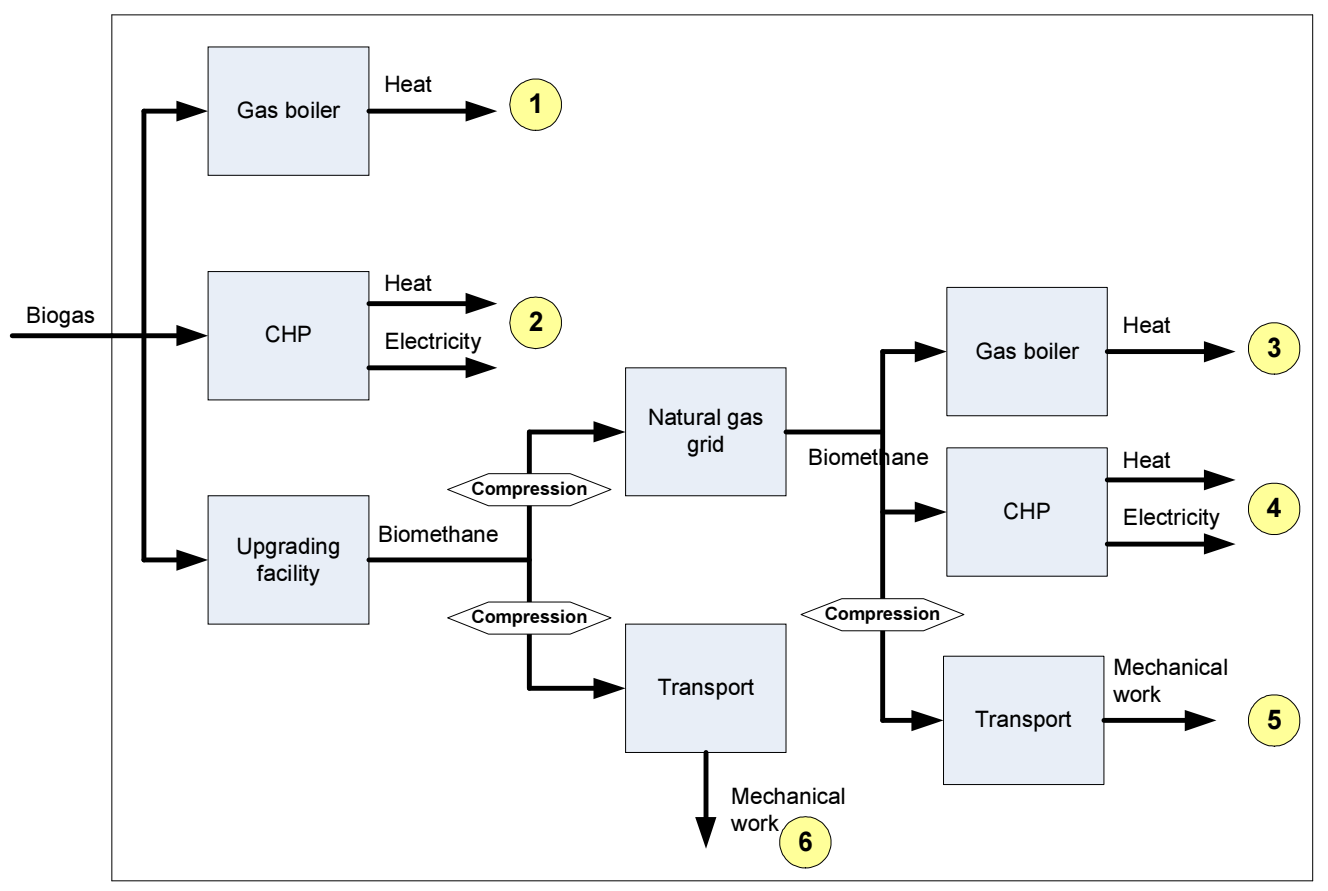

Fig. 2. Boundary of the conducted study and six biogas-to-energy conversion pathways

Six various biogas-to-energy conversion pathways are analysed in this study (see Fig. 2):

1. Biogas to heat

2. Biogas to heat and power (CHP)

3. Biomethane with grid injection to heat

4. Biomethane with grid injection to heat and power (CHP)

5. Biomethane with grid injection to transport

6. Biomethane directly to transport

\subsection{Multi-criteria analysis}

The multi-criteria analysis is used for the comparative analysis of a range of alternatives; and the result is normally provided through a weighted sum of a set of criteria. Multi-criteria analysis has been proved as a rather quick and simple method used in several studies related to the assessment of the sustainability within the renewable energy systems [7]. The core of the multi-criteria analysis is based on a simple multi-objective matrix. The criteria identified are reduced into a single-score objective through a procedure that determines their relative importance by multiplying each criterion with a weighting factor. The procedure of selecting the criteria categories is of the utmost importance, since a quantitative evaluation must be carried out in relation to the reference indicators [8].

In the current study, the multi-criteria analysis is employed for the evaluation of the versatile benefits and/or impacts of different biogas use scenarios. The level of sustainability is a key aspect to be determined, which is illustrated through different spheres of interest (or dimensions) within the multi-criteria analysis. These dimensions cover the environmental, financial, socio-economic [9], and technical perspectives [8]. 
The importance of other tools can also be highlighted. For instance, Life Cycle Assessment (LCA), where shifting the burden is avoided by incorporating the holistic approach, can be used. However, the lack of clear and adequate indicators for the social and economic aspect is a bottleneck of this method [10].

In light of the aforementioned reasons, the multi-criteria analysis represents appropriate tool for decision-making, which provides quantitative solutions to qualitative problems and helps decision-makers select the optimal solution among the proposed alternatives.

The guidelines on how to carry out a multi-criteria analysis can be found [11]. A brief description of the procedure is described hereafter:

- definition of the problem (base scenario);

- definition of the evaluation matrix (i.e. main actors in process, alternative strategies);

- definition of the potential tools to be implemented;

- criteria evaluation;

- criteria weights;

- aggregation of weighted results;

- ranking of the scenarios;

- results discussion and recommendations.

The most prominent bottlenecks of the whole system are related to the socio-economic aspect. The complexity of socioeconomic dimension makes its evaluation difficult, and the representation through quantitative models increases the inaccuracy and, consequently, reduces the meaning of the structural elements of the full model.

A simple choice for the evaluation of the sustainability assessment of a system is proposed by Nzila et al. [10], who defined measurable criteria related to the environmental, technical, and economic dimensions. Thus, the sustainability indicators can be used as a benchmark aiding the decision-making process.

Achieving a "single-score" final result of sustainability through the multi-criteria analysis is a complex task. In fact, it depends on the articulated set of indicators providing a holistic view about the level of sustainability to decision-makers and the general public.

\subsection{Choice of MCA indicators within a TOPSIS modelling}

The Technique for Order of Preference by Similarity to Ideal Solution (TOPSIS) was applied for the evaluation and selection of the optimal biogas use pathway. TOPSIS has been developed by Hwang and Yoon [12]. The aim of this method is to aid the decision-making by ranking alternatives in accordance to their closeness to the ideal solution [13].

Technological: Values for the technical dimension are represented by the different types of the maturity of the analysed scenarios (grade from 1 to 4 in terms of basic and applied (R\&D) level of technology, demonstration technology, early commercial technology and commercial technology) together with the type of the overall process efficiency. These values were selected from literature $[3,4,6,14]$.

Economic: For the economic dimension, data from Literature were used [3, 4, 6].

Environmental: Values for the environmental dimension are represented by the avoided Greenhouse gas emissions calculated according to the emission factors from the use of a fossil fuel [15].

Social: The social dimension indicators is based on experts' opinion and mainly associate to the potential benefit for the society for local use the energy final output (grade from 1 to 3 in term of low, average, high benefit on local use).

\section{Application of the developed method to the case of Latvia}

\subsection{Biogas market and support policy in Latvia}

The history of biogas production in Latvia started in the early 1980's in several dairy plants and pig farms with experimental studies on new methods for wastewater treatment and production of natural fertilizer. After a period of silence, over the past decade, the biogas sector has started to develop again. The development of the Latvian biogas market was initiated by the introduction of new RES support policy - electricity feed-in tariff, guaranteed payment for installed capacity and investment grants. The installed biogas capacity has increased from around $7 \mathrm{MW}_{\mathrm{el}}$ in 2005 to $20 \mathrm{MW}_{\mathrm{el}}$ in 2010.

In 2010 the annual electricity production from biogas reached $45 \mathrm{GWh}$ which made $0.6 \%$ of the total electricity consumption and $1.3 \%$ of renewable electricity production in Latvia. In 2011 the number of biogas plants and amount of produced electricity increased more than twice. By the end of 2013 there were around 50 operating biogas plants and more biogas plants were in the planning or construction process.

The average installed electrical capacity of a biogas plant is around $1 \mathrm{MW}_{\mathrm{el}}$. The most common substrates used for biogas production are silage crops (e.g. maize, grass) and livestock manure from pig and cattle farms. Other types of feedstock used in biogas plants are sewage sludge from wastewater treatment plants and organic waste, municipal solid waste and waste from the food and beverage industry.

In order to achieve the 2020 target for biogas, it will be necessary to evaluate the success of existing support mechanism and make some improvements in the upcoming years. According to the National Renewable Energy Action Plan, the 
installed biogas capacity will reach $92 \mathrm{MW}_{\text {el. }}$. This will allow producing $584 \mathrm{GWh}$ of electricity from biogas in 2020 (see Fig. 3).

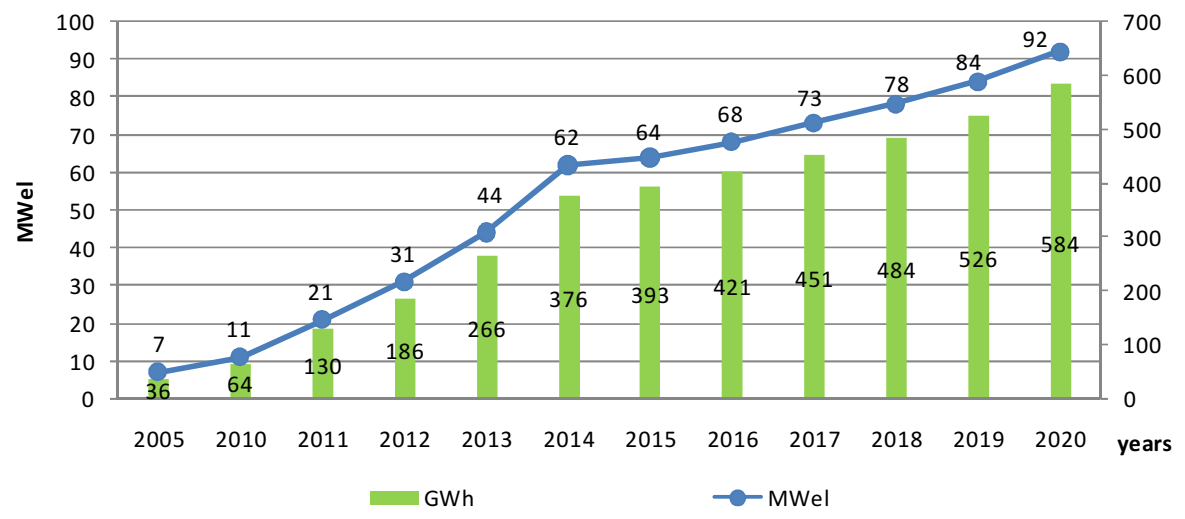

Fig. 3. Biogas target for Latvia in 2020 [16]

The main law establishing support mechanisms for renewable energy sources (including biogas) in Latvia is the Electricity Market Law adopted on 5 May 2005 [17]. The Electricity Market Law states that a certain part of the total consumption of the electricity by end users shall be covered by the electricity produced from renewable energy resources. According to the Electricity Market Law, energy production from biogas in Latvia is supported through two mechanisms:

- Mandatory purchase of electricity generated from renewable energy sources (feed-in tariff) or guaranteed payment for installed capacity for installations with installed electrical capacity more than $1 \mathrm{MWel}$ and at least 8000 operation hours per year.

- Mandatory purchase of electricity generated in CHP plants (feed-in tariff) or guaranteed payment for installed capacity for installations with installed electrical capacity of more than $20 \mathrm{MW}_{\mathrm{el}}$ and at least 3000 operation hours per year.

However, the energy producer may choose only one of the two proposed support mechanisms and it is not possible to combine them. No plants with biogas upgrading are yet in operation in Latvia. This is mainly due to the lack of incentives and support mechanisms for biomethane use.

The natural gas market in Latvia in practice is not liberalized and no legal framework has been developed to allow the third party access to the natural gas grids. The agreement between the only natural gas grid operator and Latvian government states that a gas company has a monopoly right to use natural gas networks till 2017.

The use of biomethane in transport is also difficult because no compressed natural gas (CNG) stations are operating in Latvia and all infrastructure needs to be built from scratch. Due to the lack of infrastructure, there is no demand for CNG cars in the market and therefore also supply of cars supporting CNG or compressed biomethane gas (CBG) use is very limited at the moment.

\subsection{Application of the multi-criteria analysis for the study of biogas use pathways in Latvia}

Within the application of the multicriteria analysis the following main data and assumptions (see Table 1) have been selected to be further implemented in the TOPSIS methodological approach. All the final results of the calculations necessary for the data input for the matrix are shown in the Table 3.

Table 1. Designation of biogas conversion pathways scenarios

\begin{tabular}{|c|c|c|c|c|}
\hline Activity/technology/parameters & Data on & Unit & Value & Based on \\
\hline \multirow[t]{5}{*}{ Transportation } & Emission factor gasoline & $\mathrm{tCO} 2 / \mathrm{MWh}_{\text {usedfuel }}$ & 0.249 & {$[15]$} \\
\hline & $\begin{array}{l}\text { Car thermal efficiency } \\
\text { using biomethane }\end{array}$ & $\%$ & 28 & {$[14]$} \\
\hline & NCV gasoline & $\mathrm{kWh} / \mathrm{kg}$ & 12.3 & {$[15]$} \\
\hline & Car average travelling & $\mathrm{Km} / \mathrm{a}$ & 17000 & [3] \\
\hline & $\begin{array}{l}\text { Grid connection from to } \\
\text { upgrading unit to re-filling } \\
\text { station (scenario 6) }\end{array}$ & $\mathrm{km}$ & 0.5 & assumption \\
\hline \multirow[t]{2}{*}{ Filling station } & Investment cost & $€ / \mathrm{MWh}_{\text {biogas }}$ & 0.33 & {$[6]$} \\
\hline & O\&M and back-up cost & $€ / \mathrm{MWh}_{\text {biogas }}$ & 8.3 & {$[6]$} \\
\hline \multirow[t]{2}{*}{ Biogas upgrading } & Investment cost & $€ / \mathrm{MWh}_{\text {biogas }}$ & 45.0 & {$[6]$} \\
\hline & O\&M & $€ / \mathrm{MWh}_{\text {biogas }}$ & 1.7 & {$[6]$} \\
\hline
\end{tabular}


End of Table 1

\begin{tabular}{|c|c|c|c|c|}
\hline Activity/technology/parameters & Data on & Unit & Value & Based on \\
\hline \multirow[t]{2}{*}{ Only heat boiler } & Investment cost & $€ / \mathrm{MWh}_{\text {biogas }}$ & 45.0 & [6] \\
\hline & $\mathrm{O} \& \mathrm{M}$ & $€ / \mathrm{MWh}_{\text {biogas }}$ & 1.7 & {$[6]$} \\
\hline \multirow[t]{4}{*}{ CHP } & Investment cost & $€ / \mathrm{MWh}_{\text {biogas }}$ & 45.0 & {$[6]$} \\
\hline & $\mathrm{O} \& \mathrm{M}$ & $€ / \mathrm{MWh}_{\text {biogas }}$ & 1.7 & {$[6]$} \\
\hline & Thermal efficiency & $\%$ & 48 & {$[6]$} \\
\hline & Electrical efficiency & $\%$ & 40 & {$[6]$} \\
\hline Technical life technologies & & years & 20 & Assumption \\
\hline Biomethane price & & $€ / \mathrm{m} 3$ & 0.528 & {$[18]$} \\
\hline Average thermal energy price & & $€ / \mathrm{kWh}$ & 0.059 & Assumption \\
\hline Feed-in tariff & & $€ / \mathrm{kWh}$ & 0.22 & \\
\hline Piping cost & & 39700 & $€ / \mathrm{km} /$ year & \\
\hline Gas grid transmission cost & & $€ / \mathrm{MWh}_{\text {biogas }}$ & 1.0 & [6] \\
\hline \multirow[t]{2}{*}{ Compression efficiency } & To the grid & MWh/MWhbiogas & 0.01 & {$[6]$} \\
\hline & For the re-filling station & MWh/MWhbiogas & 0.023 & [6] \\
\hline Upgrading efficiency & & MWh/MWhbiogas & 0.016 & [3] \\
\hline \multirow[t]{2}{*}{ Losses of natural gas } & Natural gas grid & $\%$ & 10 & [19] \\
\hline & Small connection & $\%$ & 1 & Assumption \\
\hline
\end{tabular}

The basic element of TOPSIS analysis is a data matrix (see Fig. 4).

$$
\begin{aligned}
& \begin{array}{llllll}
x_{1} & x_{2} & \cdots & x_{j} & \cdots & x_{n}
\end{array} \\
& \begin{array}{c}
A_{1} \\
A_{2} \\
\vdots \\
A_{i} \\
\vdots \\
A_{n}
\end{array}\left[\begin{array}{cccccc}
x_{11}^{k} & x_{12}^{k} & \cdots & x_{1 j}^{k} & \cdots & x_{1 n}^{k} \\
x_{21}^{k} & x_{22}^{k} & \cdots & x_{2 j}^{k} & \cdots & x_{2 n}^{k} \\
\vdots & \vdots & \cdots & \vdots & \cdots & \vdots \\
x_{i 1}^{k} & x_{i 2}^{k} & \cdots & x_{i j}^{k} & \cdots & x_{i m}^{k} \\
\vdots & \vdots & \cdots & \vdots & \cdots & \vdots \\
x_{n 1}^{k} & x_{n 2}^{k} & \cdots & x_{n j}^{k} & \cdots & x_{n m}^{k}
\end{array}\right]
\end{aligned}
$$

Fig. 4. TOPSIS decision-making matrix

There $\left\{A_{1}, A_{2}, \ldots, A_{i}, . ., A_{n}\right\}$ represents alternatives. During the research, 6 biogas use pathways (alternatives) were evaluated and compared in order to find the most feasible alternative (see Table 2).

Table 2. Designation of biogas conversion pathways scenarios

\begin{tabular}{ll}
\hline Designation & Biogas conversion pathway \\
\hline $\mathrm{A}_{1}$ & Biogas to heat \\
$\mathrm{A}_{2}$ & Biogas to heat and power $(\mathrm{CHP})$ \\
$\mathrm{A}_{3}$ & Biomethane with grid injection to heat \\
$\mathrm{A}_{4}$ & Biomethane with grid injection to heat and power (CHP) \\
$\mathrm{A}_{5}$ & Biomethane with grid injection to transport \\
$\mathrm{A}_{6}$ & Biomethane directly to transport \\
\hline
\end{tabular}

Evaluation criteria are represented by $x_{1}, x_{2}, \ldots, x_{j}, \ldots, x_{n}$ (see Fig. 4 ).

Seven criteria from four impact dimensions were selected for the evaluation of identified scenarios. All the input values for Latvian context are shown in Table 2.

As can be seen in Table 3, different criteria are related to different dimensions. The normalization of the values was carried out in order to make these data comparable and, afterwards, rank alternatives in accordance to their closeness to the Positive Ideal Solution. In this case, normalized values $\left(b_{i j}\right)$ were obtained using Jüttler's -Körth's [20] linear normalization method. 
Table 3. Input data for a TOPSIS analysis for biogas use alternative for Latvia

\begin{tabular}{|c|c|c|c|c|c|c|c|c|}
\hline \multirow{3}{*}{\multicolumn{2}{|c|}{\begin{tabular}{|rr} 
& Dimension \\
Weight \\
Criterion \\
\end{tabular}}} & \multirow{3}{*}{\begin{tabular}{|c|} 
Environmental \\
$25 \%$ \\
$\mathrm{C} 1$ \\
\end{tabular}} & \multicolumn{2}{|l|}{ Technical } & \multicolumn{3}{|l|}{ Economic } & \multirow{3}{*}{\begin{tabular}{|r|}
\multicolumn{1}{|l|}{ Social } \\
$25 \%$ \\
C7 \\
\end{tabular}} \\
\hline & & & \multicolumn{2}{|c|}{$25 \%$} & \multicolumn{3}{|c|}{$25 \%$} & \\
\hline & & & $\mathrm{C} 2$ & $\mathrm{C} 3$ & $\mathrm{C} 4$ & $\mathrm{C} 5$ & $\mathrm{C6}$ & \\
\hline & Unit measure & $\begin{array}{c}\mathrm{kgCO} 2 \mathrm{eq} / \mathrm{Nm} 3 \\
\text { biogas }\end{array}$ & $\%$ & grades & E/MWhbiogas & E/MWhbiogas & E/MWhbiogas & grades \\
\hline & Specific weights & 0,250 & 0,163 & 0,088 & 0,075 & 0,075 & 0,100 & 0,250 \\
\hline $\mathrm{A} 1$ & Biogas for heat production - i.e. boiler house & 1,1716 & 90,00 & 4,00 & 0,75 & 1,91 & 28,48 & 2 \\
\hline A2 & Biogas to heat and power (CHP) & 1,1716 & 88,00 & 4 & 4,30 & 4,85 & 88,00 & 3 \\
\hline A3 & Biomethane with grid injection to heat & 1,0544 & 79,02 & 3 & 2,7 & 46,65 & 44,01 & 2 \\
\hline A4 & Biomethane with grid injection to heat and power (CHP) & 1,0544 & 77,26 & 3 & 2,7 & 46,65 & 44,01 & 3 \\
\hline A5 & Biomethane with grid injection to transport & 0,0010 & 63,65 & 3 & 11,00 & 46,68 & 44,01 & 1 \\
\hline A6 & Biomethane directly to transport & 0,0012 & 69,39 & 3 & 10,00 & 46,68 & 44,01 & 1 \\
\hline
\end{tabular}

If $\max x_{i j}$ is preferable, then $b_{i j}$ is calculated using Eqn (1). If $\min x_{i j}$ is preferable, the Eqn (2) is used.

$$
\begin{aligned}
& b_{i j}=\frac{\max x_{i j}-x_{i j}}{\max x_{i j}-\min x_{i j}}, \\
& b_{i j}=\frac{x_{i j}-\min x_{i j}}{\max x_{i j}-\min x_{i j}},
\end{aligned}
$$

Normalized data are also arranged in a matrix and then weighed multiplying them with the criteria's weights $\left(w_{j}\right)($ see Fig. 5).

$$
\begin{aligned}
& \begin{array}{llllll}
w_{1} b_{1} & w_{2} b_{2} & \cdots & w_{j} b_{j} & \cdots & w_{n} b_{n}
\end{array} \\
& A_{1}\left[\begin{array}{cccccc}
w_{1} b_{11}^{k} & w_{2} b_{12}^{k} & \cdots & w_{j} b_{1 j}^{k} & \cdots & w_{n} b_{1 n}^{k}
\end{array}\right] \\
& A_{2} w_{1} b_{21}^{k} \quad w_{2} b_{22}^{k} \quad \cdots \quad w_{j} b_{2 j}^{k} \quad \cdots \quad w_{n} b_{2 n}^{k} \\
& \begin{array}{lllllll}
\vdots & \vdots & \vdots & \cdots & \vdots & \ldots & \vdots
\end{array} \\
& A_{i} \quad \begin{array}{llllll}
w_{1} b_{i 1}^{k} & w_{2} b_{i 2}^{k} & \cdots & w_{j} b_{i j}^{k} & \cdots & w_{n} b_{i m}^{k}
\end{array} \\
& \begin{array}{ccccccc}
\vdots & \vdots & \vdots & \ldots & \vdots & \ldots & \vdots
\end{array} \\
& A_{n}\left[\begin{array}{llllll}
w_{1} b_{n 1}^{k} & w_{2} b_{n 2}^{k} & \cdots & w_{j} b_{n j}^{k} & \cdots & w_{n} b_{n m}^{k}
\end{array}\right]
\end{aligned}
$$

\begin{tabular}{|c|c|c|c|c|c|c|c|}
\hline Dimension & Environmental & \multicolumn{2}{|c|}{ Technical } & \multicolumn{3}{|c|}{ Economic } & Social \\
\hline Weight & $25 \%$ & \multicolumn{2}{|c|}{$25 \%$} & \multicolumn{3}{|c|}{$25 \%$} & $25 \%$ \\
\hline Criterion & $\mathrm{Cl}$ & $\mathrm{C} 2$ & $\mathrm{C} 3$ & $\mathrm{C} 4$ & $\mathrm{C} 5$ & C6 & $\mathrm{C} 7$ \\
\hline Unit measure & kgCO2eq/Nm3 biogas & $\%$ & grades & €/MWhbiogas & €/MWhbiogas & €/MWhbiogas & grades \\
\hline Specific weights & 0,250 & 0,163 & 0,088 & 0,075 & 0,075 & 0,100 & 0,250 \\
\hline
\end{tabular}

Fig. 5. Normalized and weighted data matrix

The weighting factors used are reported in the following table assuming an equal contribution from the principle four

\begin{tabular}{|c|c|c|c|c|}
\hline Dimension & $\begin{array}{l}\text { Environmental } \\
\text { (contribution) }\end{array}$ & $\begin{array}{l}\text { Technical } \\
\text { (contribution) }\end{array}$ & $\begin{array}{l}\text { Economical } \\
\text { (contribution) }\end{array}$ & $\begin{array}{l}\text { Social } \\
\text { (contribution) }\end{array}$ \\
\hline Rating 1 - Baseline scenario & $25 \%$ & $5 \%$ & $5 \%$ & $5 \%$ \\
\hline Rating $2-$ Economical oriented & $20 \%$ & $20 \%$ & $40 \%$ & $20 \%$ \\
\hline Rating 2 - Environmental oriented & $40 \%$ & $20 \%$ & $20 \%$ & $20 \%$ \\
\hline Rating 2-Balanced oriented & $35 \%$ & $15 \%$ & $35 \%$ & $15 \%$ \\
\hline
\end{tabular}
dimensions considered (i.e. environmental, technical, economic and social) and are reported in Table 4. The weight of the Criteria $\left(w_{1}, w_{2}, \ldots, w_{n}\right)$ was determined by experts.

Table 4. Weighting factors

Moreover the effect of sensitivity analysis among the weighting of four dimensions has been proposed. A total number of four potential situations have been proposed in order to evaluate the effect of different perspective of the initial weighting proposed. These have been defined with the following ratings.

Table 5. Sensitivity analysis scenarios of the fours dimensions implemented within the multicriteria analysis 
Normalized and weighted values from the decision-making matrix for the evaluation of the six biogas scenarios for Latvian conditions are displayed in Table 6.

Table 6a. Normalized and weighted decision-making matrix for the rating 1

\begin{tabular}{|c|c|c|c|c|c|c|c|}
\hline \multirow{3}{*}{$\begin{array}{r}\text { Dimension } \\
\text { Weigh } \\
\text { Criterion }\end{array}$} & \multirow{3}{*}{\begin{tabular}{|c|} 
Environmental \\
$25 \%$ \\
$\mathrm{C} 1$ \\
\end{tabular}} & \multicolumn{2}{|l|}{ Technical } & \multicolumn{3}{|l|}{ Economic } & \multirow{3}{*}{\begin{tabular}{|c|} 
Social \\
$25 \%$ \\
$\mathrm{C} 7$ \\
\end{tabular}} \\
\hline & & \multicolumn{2}{|c|}{$25 \%$} & \multicolumn{3}{|c|}{$25 \%$} & \\
\hline & & $\mathrm{C} 2$ & $\mathrm{C} 3$ & $\mathrm{C} 4$ & $\mathrm{C} 5$ & C6 & \\
\hline Unit measure & wlbil & w2bi2 & w3bis & w4tbi4 & w5bi5 & w6bi6 & grades \\
\hline Biogas for heat production - i.e. boiler house & 0,0000 & 0,0000 & 0,00 & 0,08 & 0,08 & 0,10 & 0,13 \\
\hline Biogas to heat and power (CHP) & 0,0000 & 0,0123 & 0,00 & 0,05 & 0,07 & 0,00 & 0,00 \\
\hline Biomethane with grid injection to heat & 0,0250 & 0,0677 & 0,09 & 0,06 & 0,00 & 0,07 & 0,13 \\
\hline Biomethane with grid injection to heat and power (CHP) & 0,0250 & 0,0786 & 0,09 & 0,06 & 0,00 & 0,07 & 0,00 \\
\hline Biomethane with grid injection to transport & 0,2500 & 0,1625 & 0,09 & 0,00 & 0,00 & 0,07 & 0,25 \\
\hline Biomethane directly to transport & 0,2500 & 0,1271 & 0,09 & 0,01 & 0,00 & 0,07 & 0,25 \\
\hline
\end{tabular}

Table $6 \mathrm{~b}$. Normalized and weighted decision-making matrix for the rating 2

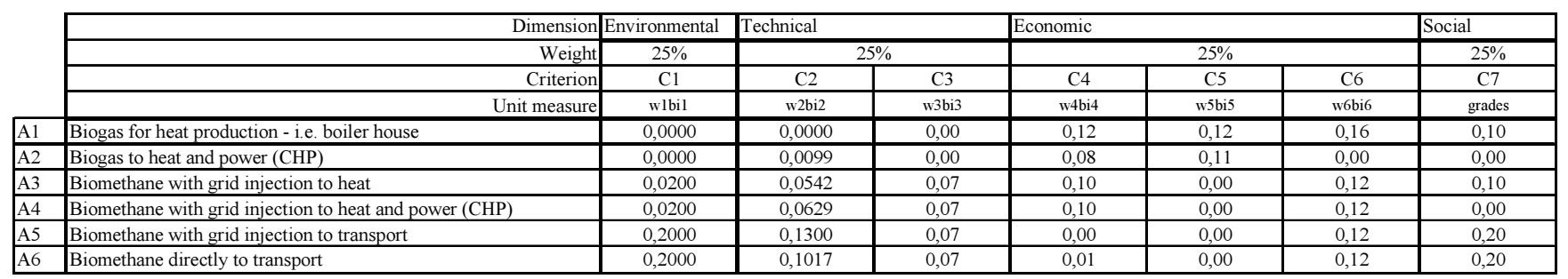

Table $6 \mathrm{c}$. Normalized and weighted decision-making matrix for the rating 3

\begin{tabular}{|c|c|c|c|c|c|c|c|c|}
\hline & \multirow{3}{*}{\begin{tabular}{r|} 
Dimension \\
Weight \\
Criterion
\end{tabular}} & \multirow{3}{*}{\begin{tabular}{|c|} 
Environmenta \\
$25 \%$ \\
$\mathrm{C} 1$ \\
\end{tabular}} & \multicolumn{2}{|l|}{ Technical } & \multicolumn{3}{|l|}{ Economic } & \multirow{3}{*}{$\begin{array}{c}\text { Social } \\
25 \% \\
\mathrm{C} 7 \\
\end{array}$} \\
\hline & & & \multicolumn{2}{|c|}{$25 \%$} & \multicolumn{3}{|c|}{$25 \%$} & \\
\hline & & & $\mathrm{C} 2$ & $\mathrm{C} 3$ & $\mathrm{C} 4$ & $\mathrm{C} 5$ & $\mathrm{C} 6$ & \\
\hline & Unit measure & wlbil & w2bi2 & w3bi3 & w4bi4 & w5bi5 & w6bi6 & grades \\
\hline $\mathrm{A} 1$ & Biogas for heat production - i.e. boiler house & 0,0000 & 0,0000 & 0,00 & 0,06 & 0,06 & 0,08 & 0,10 \\
\hline $\mathrm{A} 2$ & Biogas to heat and power (CHP) & 0,0000 & 0,0099 & 0,00 & 0,04 & 0,06 & 0,00 & 0,00 \\
\hline $\mathrm{A} 3$ & Biomethane with grid injection to heat & 0,0400 & 0,0542 & 0,07 & 0,05 & 0,00 & 0,06 & 0,10 \\
\hline $\mathrm{A} 4$ & Biomethane with grid injection to heat and power (CHP) & 0,0400 & 0,0629 & 0,07 & 0,05 & 0,00 & 0,06 & 0,00 \\
\hline A5 & Biomethane with grid injection to transport & 0,4000 & 0,1300 & 0,07 & 0,00 & 0,00 & 0,06 & 0,20 \\
\hline $\mathrm{A} 6$ & Biomethane directly to transport & 0,4000 & 0,1017 & 0,07 & 0,01 & 0,00 & 0,06 & 0,20 \\
\hline
\end{tabular}

Table $6 \mathrm{~d}$. Normalized and weighted decision-making matrix for the rating 4

\begin{tabular}{|c|c|c|c|c|c|c|c|c|}
\hline & & \multirow{2}{*}{\begin{tabular}{|c|} 
Environmenta \\
$25 \%$ \\
\end{tabular}} & \multicolumn{2}{|l|}{ Technical } & \multicolumn{3}{|l|}{ Economic } & \multirow{3}{*}{$\begin{array}{r}\text { Social } \\
25 \% \\
\text { C7 }\end{array}$} \\
\hline & Weight & & \multicolumn{2}{|c|}{$25 \%$} & \multicolumn{3}{|c|}{$25 \%$} & \\
\hline & Criterion & $\mathrm{Cl}$ & $\mathrm{C} 2$ & $\mathrm{C} 3$ & $\mathrm{C} 4$ & $\mathrm{C} 5$ & $\mathrm{C} 6$ & \\
\hline & & wlbil & w2bi2 & w3bi3 & w4bi4 & w5bi5 & w6bi6 & grades \\
\hline $\mathrm{Al}$ & Biogas for heat production - i.e. boiler house & 0,0000 & 0,0000 & 0,00 & 0,11 & 0,11 & 0,14 & 0,08 \\
\hline $\mathrm{A} 2$ & Biogas to heat and power (CHP) & 0,0000 & 0,0074 & 0,00 & 0,07 & 0,10 & 0,00 & 0,00 \\
\hline $\mathrm{A} 3$ & Biomethane with grid injection to heat & 0,0350 & 0,0406 & 0,05 & 0,09 & 0,00 & 0,10 & 0,08 \\
\hline $\mathrm{A} 4$ & Biomethane with grid injection to heat and power (CHP) & 0,0350 & 0,0471 & 0,05 & 0,09 & 0,00 & 0,10 & 0,00 \\
\hline A5 & Biomethane with grid injection to transport & 0,3500 & 0,0975 & 0,05 & 0,00 & 0,00 & 0,10 & 0,15 \\
\hline $\mathrm{A} 6$ & Biomethane directly to transport & 0,3500 & 0,0763 & 0,05 & 0,01 & 0,00 & 0,10 & 0,15 \\
\hline
\end{tabular}

The next step of the TOPSIS analysis is the determination of the Positive and Negative Ideal solution. Positive Ideal solution is determined using Eqn (3), Negative Ideal solution is calculated according to Eqn (4).

$$
\begin{aligned}
& A^{+}=\max _{i} w_{j} b_{i j} \\
& A^{-}=\min _{i} w_{j} b_{i j}
\end{aligned}
$$

Separation from Positive Ideal solution $\left(\mathrm{S}^{+}\right)$is calculated with Eqn (5) and Separation from Negative Ideal solution ( $\mathrm{S}^{-}$) is calculated with Eqn (6).

$$
\begin{aligned}
& S^{+}=\sqrt{\sum_{j=1}^{n}\left(v_{i j}-v_{i j}^{+}\right)^{2}}, \quad i=1,2, \ldots, m \\
& S^{-}=\sqrt{\sum_{j=1}^{n}\left(v_{i j}-v_{i j}^{-}\right)^{2}}, \quad i=1,2, \ldots, m
\end{aligned}
$$


Last step is calculation of alternatives Relative Closeness to the Ideal Solution (see Eqn 7).

$$
C_{i}^{*}=\frac{S_{i}^{+}}{\left(S_{i}^{+}-S_{i}^{-}\right)}, \quad i=1,2, \ldots, m
$$

The obtained number is in the range [0;1] and shows the alternative rating. If $C_{i}^{*}=1$, the alternative is equal to the Ideal solution, if $C_{i}^{*}=0$ it is the opposite of the Ideal solution. The closer the rating is to 1 , the better is the alternative. Table 4 shows the TOPSIS analysis results for the proposed scenario. The results show that the best results, around 0.9 , were always achieved by the scenario $A_{2}$, while the second place is fluctuation among the scenario $A_{1}, A_{3}$ and $A_{4}$.

Table x. TOPSIS analysis results for Latvia

\begin{tabular}{|l|l|l|l|l|l|}
\hline \multicolumn{2}{|l|}{ Scenario } & Rating 1 & Rating 2 & Rating 3 & Rating 4 \\
\hline A1 & Biogas for heat production - i.e. boiler house & 0.699 & 0.640 & 0.805 \\
\hline A2 & Biogas to heat and power (CHP) & $\mathbf{0 . 9 1 2}$ & $\mathbf{0 . 8 6 1}$ & $\mathbf{0 . 9 4 4}$ & $\mathbf{0 . 9 0 0}$ \\
\hline A3 & Biomethane with grid injection to heat & 0.651 & 0.573 & 0.765 & 0.692 \\
\hline A4 & Biomethane with grid injection to heat and power (CHP) & 0.743 & 0.626 & 0.814 & 0.714 \\
\hline A5 & Biomethane with grid injection to transport & 0.064 & 0.102 & 0.040 & 0.073 \\
\hline A6 & Biomethane directly to transport & 0.073 & 0.112 & 0.046 & 0.080 \\
\hline
\end{tabular}

The obtained results show the effects on the maturity in connection with the technology implemented in the selected scenario. In fact a lower level of both investment and maintenance cost within the scenario A2 (Biogas to heat and power) together with the same trend evident as well for the scenario Al (Biogas for heat production) thus enhancing the option to directly use biogas both for the thermal and electrical energy production. The same aspect is reflected when the upgrading operation is implemented. The refilling into the grid of the biomethane represents still valuable solutions from a MCA perspective.

The final end use into the transportation sector seems to be in the opposite direction probably due to the relevant costs and technical difficulties related to the re-filling station and the compression to $20 \mathrm{bar}$ in order to be use in vehicles.

Finally TOPSIS analysis results show that there is one evident better solution (Biogas for heat production - i.e. boiler house) and three close to the optimal solutions.

Further analyses are required in order to better understand how the integration of other relevant criteria will affect the results and how specific sensitivity analysis on the input data used could eventually change the finale rate.

\section{Conclusions and recommendations}

Biogas has different pathways of end use (i.e. direct combustion with the production of only heat, combined heat and power (CHP) generation, upgrading with later use as vehicle fuel or injection in the natural gas grid). The assessment of the feasibility and performance of a single is dependent from several criteria of evaluation (not specifically the economical aspect). This study proposed an assessment through a multidisciplinary approach involving economic, environmental, technical and social perspectives.

Six different scenarios including direct biogas combustion, use of biogas in a CHP system, and biogas upgrading to biomethane have Benn investigated. The identified set of criteria is applied to the Latvian biogas market as a case study in order to provide a consistent and holistic final overview through the use of the TOPSIS method.

The main general conclusions from the proposed study can be summarized as:

1. The six identified scenarios are potentially exploitable biogas routes.

2. The proposed indicators represents a first set of important from which it is possible to carry out holistic evaluation of the scenarios proposed.

3. The main indicators for the assessment of biogas routes are: fossil fuel substitution in terms of replaced greenhouse gas emissions, efficiency, maturity of the technology, operational and investment costs, revenues, potential benefit for the society for local use the energy final output.

3. The holistic approach used and the implementation of four dimensions (i.e. social, economic, environmental, and technical) represents a good optimization method useful for stakeholder and policy makers, meaning that local actors could choose the optimal strategy among a selected number of possibility depending as well from local factors.

4. The results from TOPSIS method show that there is one evident better solution (Biogas for heat production - i.e. boiler house) and three close to the optimal solutions.

The final end use into the transportation sector seems to be the worst scenario.

5. Further analysis concerning the validation of the adopted weightings within the TOPSIS method is necessary. 


\section{Acknowledgements}

This work has been supported by the European Social Fund project "Involvement of Human Resources for Development of Integrated Renewable Energy Resources Energy Production System" (project No. 2013/0014/1DP/1.1.1.2.0/13/APIA/ VIAA/026).
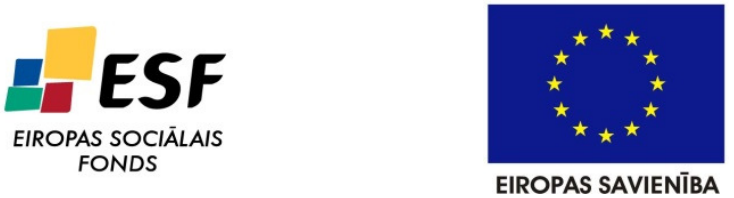

\section{IEGULDĪJUMS TAVĀ NĀKOTNĒ}

\section{References}

[1] Havukainen, J.; Uusitalo, V.; Niskanen, A.; Kapustina, V.; Horttanainen M. 2014. Evaluation of methods for estimating energy performance of biogas production, Renewable Energy 66(2014): 232-240. http://dx.doi.org/10.1016/j.renene.2013.12.011

[2] Press release of the European Commission IP/14/54. 2030 climate and energy goals for a competitive, secure and low-carbon EU economy, 22/01/2014.

[3] Goulding, D.; Power, N. 2013. Which is the preferable biogas utilisation technology for anaerobic digestion of agricultural crops in Ireland: Biogas to CHP or biomethane as a transport fuel?, Renewable Energy 53(2013): 121-131. http://dx.doi.org/10.1016/j.renene.2012.11.001

[4] Pöschl, M.; Ward, S.; Owende, P. 2010. Evaluation of energy efficiency of various biogas production and utilization pathways, Applied Energy 87(2010): 3305-3321. http://dx.doi.org/10.1016/j.apenergy.2010.05.011

[5] Murphy, J. D.; McKeogh, E.; Kiely, G. 2004. Technical/economic/environmental analysis of biogas utilisation, Applied Energy 77(2004): $407-427$. http://dx.doi.org/10.1016/j.apenergy.2003.07.005

[6] Börjesson, M.; Ahlgren, E. O. 2012. Cost-effective biogas utilisation - A modelling assessment of gas infrastructural options in a regional energy system, Energy 48(2012): 212-226. http://dx.doi.org/10.1016/j.energy.2012.06.058

[7] Integrated Analysis of Hybrid Systems for Rural Electrification in Developing Countries, M.Sc. Thesis, RIT Division of Land and Water and Water Resources Engineering, Stockholm, Sweden. Available online http://www2.lwr.kth.se/Publikationer/PDF_Files/LWR_EX_04_26.PDF (accessed 24.11.13.).

[8] Wang, J. J.; Jing, Y.Y.; Zhang, C. F.; Zhao, J. H. 2009. Review on multi-criteria decision analysis aid in sustainable energy decision-making. Renew Sust Energ Rev. 13: 2263-2278. http://dx.doi.org/10.1016/j.rser.2009.06.021

[9] Finkbeiner, M.; Schau, E. M.; Lehmann, A.; Traverso, M. 2010. Towards life cycle sustainability assessment, Sustainability 2: 3309-3322. http://dx.doi.org/10.3390/su2103309

[10] Nzila, C.; Dewulf, J.; Spanjers, H.; Tuigong, D.; Kiriamiti, H.; Langenhove, H. 2012. Multi criteria sustainability assessment of biogas production in Kenya, Applied Energy 93: 496-506. http://dx.doi.org/10.1016/j.apenergy.2011.12.020

[11] Georgopoulou, E.; Lalas, D.; Papagiannakis, L. 1997. A Multicriteria Decision Aid approach for energy planning problems: The case of renewable energy option, Eur J Oper Res. 103: 38-54. http://dx.doi.org/10.1016/S0377-2217(96)00263-9

[12] Hwang, C. L.; Yoon, K. 1981. Multiple Attribute Decision Making: Methods and Applications Springer-Verlag, Heidelbeg. http://dx.doi.org/10.1007/978-3-642-48318-9

[13] Tzeng, G. H.; Huang, J. J. 2011. Multiple Attribute Decision Making: Methods and Applications. Taylor \& Francis, Boca Raton, United States of America.

[14] Amir-Hasan Kakaee, A-H.; Paykani, A. 2013. Research and developmen tof natural-gasfueled engines in Iran, Renewable and Sustainable EnergyReviews 26: 805-821. http://dx.doi.org/10.1016/j.rser.2013.05.048

[15] European Union (EU), How To Develop A Sustainable Energy Action Plan (SEAP) - Guidebook Part 2.: Publications Office of the European Union, 2010. http://www.eumayors.eu/IMG/pdf/seap_guidelines_en.pdf. 2010, European Union.

[16] Information Report: Republic of Latvia National Renewable Energy Action Plan for implementing Directive 2009/28/EC of the European Parliament and of the Council of 23 April 2009 on the promotion of the use of energy from renewable sources and amending and subsequently repealing Directives 2001/77/EC and 2003/30/EC by 2020, The Ministry of Economics of Latvia, 2010.

[17] Electricity Market Law addopted by Saeima and proclaimed by the President of Latvia on 05.05.2005, in force since 08.06.2005.

[18] Latvijas Gāze, http://www.lg.lv/?id=122

[19] Arnórsson, H. 2011. A feasibility study of using biomethane as an alternative fuel for taxis in the reykjavík capital area. 2011. A Master's thesis done at RES -The School for Renewable Energy Science in affiliation with University of Iceland.

[20] Körth, H. 1969. Zur Berücksichtigung mehrer Zielfunktionen bei der Optimierung von Produktionsplanen, Mathematik und Wirtschaft 6: 184-201. 